\title{
Effect of Religious Beliefs on Quality of Translation
}

\author{
Sarah Yousefi \\ Faculty of Foreign Languages and Literature, Islamic Azad University Science and Research Branch, Tehran, Iran
}

Received: 19-02-2017

doi:10.7575/aiac.ijclts.v.5n.2p.32
Accepted: 15-04-2017

Published: 30-04-2017

\begin{abstract}
Quality of translation has become one of the main focuses in the field of Translation Studies. When it comes to the religious texts and their translations, quality of translation becomes more and more important as these texts are directly connected to the beliefs of followers of a specific religion, and since many of the religious texts have been written many years ago, and now the followers of that religion are neither able to learn the language of their religions nor have enough time to do so, delivering high quality translations is very crucial. In recent years, many translation scholars have focused on Translation Quality Assessment (TQA) to provide ways to translators and translation teachers to assess the quality of translations and consequently to overcome translation problems. In the present research, the researcher attempted to combine both of the aforementioned subjects. In order to achieve this goal, the researcher selected Waddington's model for assessing the quality of translations, to see if the quality of translations of Islamic texts which were translated by Muslim translators were higher than those which were translated by non-Muslims. Two groups of translators were selected, one of them was Muslim and the other one was non-Muslim. Each group consisted of 10 translators, each of them translated 5 Islamic-religious texts, and after assessing the quality of translations and doing statistical analyses, researcher concluded that there was no relation between the quality of translations and the religious beliefs of translators.
\end{abstract}

Keywords: Ideology, Religious Texts, Religious Language, Translation Quality Assessment

\section{Introduction}

Naeem et al. (2014, p.40) define language of religion as a language “.... totally different from the everyday language. It is the language in which certain aspects of everyday language are altered or sometimes suspended. Language of religion is considered prior to everyday language" Harison (2007) holds the idea that religious language is the type of language which is used routinely by religious experts so that they can express their beliefs and ideas. Every type of text and its translation has its own specific addressee, and regarding the Islamic-religious texts and their translations, it can be said that the main addressees of these texts and translations are Muslims, Muslim communities and those who are interested in reading Islamic-religious texts and are willing to research in this field. Religious texts are really important to societies as Rabbani (2007) believes that religious texts are the basis of inspirational teachings and by the help of teachings and beliefs human beings are raised to the highest level.

Dweik and Abu Helwah (2014, p. 286) refer to religious texts as "expressive texts". They believe these texts are "peculiar in that in addition to their having a sacred nature, they address the minds together with the hearts of their audience." Hervey, Dickins, and Higgins (2002, p.178) hold that "the subject matter of religious texts implies the existence of a spiritual world that is not fictive, but has its own external realities and truths." According to Webb Keane (1997, p.47) "In contrast to less marked speech situations, in religious contexts the sources of words, as well as the identity, agency, authority, and even the very presence of participants in an interaction, can be especially problematic."

Elewa (2014) considers specialized lexical items as the main important feature of the religious translation which at the end can cause difficulties for translators and they must be aware of them. He believes that translation of religious texts can also be important, as he (p.25) says "Translation of religious texts has been a key element in disseminating the divine message throughout history. It was employed also for teaching converts the basics of religion and for mirroring the beauty of faith and morality around the globe." Farsian and Esmaieli (2004) argue that these days as Islam spreads around the world and as the number of Muslims increases significantly, the importance of translation of religious and Islamic texts becomes more and more obvious than before. Jahanshahi and Kafipour (2015) are among all those who emphasis on translation of Islamic-religious texts, they believe that:

The translation of Islamic texts is of great importance since these texts are considered as the key texts for spreading out the Islamic thoughts. Therefore, if the translator commits an error in this sensitive realm, the content may be altered. (Jahanshahi and Kafipour, 2015, p.239)

Doing researches in translation of Islamic texts in countries such as Iran, which translation of religious texts has been focused from the very first days of arrival of Islam to the country, is really important and useful. All of the researches which have been done on translation of Islamic-religious texts can be useful either for those who are willing to work as a professional translators or those who are willing to assess the quality of the previously done translations, it can also be 
helpful to the translators who work on the texts which have been previously translated and the results of these studies help them provide better translations.

Although Jacobus A. Naudé (as cited in Gambier and Doorslaer, 2010) believes that there is no difference between translation of religious texts and other genres, focusing on translations of Islamic-religious texts are very important to Muslims and Muslim communities, and researches which have been done on these translations are valuable and worthwhile too. Many of the works and studies on translations of Islamic-religious texts have been focused on the translations from different points of view. Ideology which in some way is defined as the religious belief of a person is one of the aspects that have been examined in translation of religious texts. Ideology is defined by Oxford Dictionary as "a system of ideas and ideals, especially one which forms the basis of economic or political theory and policy." Ahmad Al-Harahsheh (2013, p.109) holds that it "is a set of ideas or expectations proposed by the dominant class in the society, or it is a way of thinking and judging other things from personal point of view."

According to López and Ramos Caro (2014, p.251) "Most of the studies on ideology have focused on exploring the essence and expression of ideological intervention in translation." Xiao-jiang (2007) argues that strategies and processes which are applied by a translator during the translation can be influenced by his ideology. Schaffner (2003) and Tymoczko (2003) believe that ideology of a translator can affect the selection of words in his translation. According to Ahmad Al-Harahsheh (2013, p.110) "ideology stems from the religious and cultural norms or values of people, so Muslim translators tend to reshape, modify or omit the original text that may have words or expressions that may be hostile or severe, according to translators." Hatim and Mason (1997, p.218) also define ideology as "a body of assumptions which reflects the beliefs and interests of an individual, a group of individuals, a social institution, etc., and which ultimately finds expression in language". As Ehteshami $(2015$, p.202) believes "It may be argued that translation is an independent profession, but indeed, it is a profession that strongly depends on ideology". It was obvious that ideology of a translator has an effect on his translations, but there was a need to research and see if the ideology of a translator could affect the quality of his translations for texts which totally were not in line with his ideology.

Assessing the quality of translation is one of the focuses of the present research which had to be correctly and fully addressed in order to gain reliable results. One of the main important aspects which have been recently focused by many translation scholars is translation quality assessment. House $(2015$, p.i) considers translation quality assessment as "one of the key issues in translation studies." she (p.1) also believes that "Translation quality assessment can thus be said to be at the heart of any theory of translation." As translation of Islamic texts is really important especially to Muslims, paying attention to the translation of these texts from quality assessment point of view has many advantages. By the help of these assessments translators can remove their deficiencies through having their translations assessed by others. It can help them to recognize what they need to work on and what they need to improve. The more translators know their problems, the better they can translate. According to Waddington (2001, p.15) "Teachers of translation use a variety of methods to evaluate their students' translations". In Malcolm Williams' opinion (2009) in these days clients, translators who work as professional translators and translatological researchers and trainee translators have more justification for observing Translation Quality Assessment.

Williams (2009) considers Translation Quality Assessment as a kind of evaluation. In order to assess the quality of translation there are some rubrics which are used by researchers and translation teachers. Khanmohammad and Osanlo (2009) introduce these rubrics. These are the Farahzad's (1992), Sainz's (1992), Beeby's (2000), and Waddington's (2001). However in order to do the present research Waddington's model was selected. Waddington's model has four methods which will be explained briefly in this section.

Method A is based on analyzing the errors and possible mistakes. According to Waddington these mistakes are grouped in the following categories:

(i) Inappropriate renderings which affect the understanding of the source text and are divided into eight categories: counter-sense, faux sens, nonsense, addition, omission, unresolved extralinguistic references, loss of meaning, and inappropriate linguistic variation (register, style, dialect, etc.),

(ii) Inappropriate renderings which affect expression in the target language and are divided into five categories: spelling, grammar, lexical items, text, and style,

(iii) Inadequate renderings which affect the transmission of either the main function or secondary functions of the source text (Waddington, 2001, p.313).

Waddington (2001) also points out that in any of these categories there is a difference between what he calls senior errors ( -2 points) and minor errors ( -1 point). He also introduces a fourth category which $(+1$ point $)$ is awarded to good solutions and ( +2 points) are to exceptionally good solutions to translations errors. Like method A, method B is based on analyzing errors. In this method negative effect of errors on overall quality of translations is considered. Method $\mathrm{C}$ of Waddington's model is a holistic method. In the third method of this model three aspects of performance of students are taken into account by a rater. The scales of the method C are shown in Table 1. Two marks are allocated for each of these five levels; therefore the rater has more freedom in rating the translations of students. He argues that a student/translator, who provides a translation in accordance with all of the criteria of a specific level, deserves to get the higher mark, whereas a student/translator whose translation is something between two levels, but is closer to the upper lever will get the lower mark. 


\begin{tabular}{|c|c|c|c|c|}
\hline Level & $\begin{array}{l}\text { Accuracy of } \\
\text { transfer of ST } \\
\text { content }\end{array}$ & $\begin{array}{l}\text { Quality of } \\
\text { expression in TL }\end{array}$ & $\begin{array}{l}\text { Degree of task } \\
\text { completion }\end{array}$ & Mark \\
\hline Level 5 & $\begin{array}{l}\text { Completion } \\
\text { transfer of ST } \\
\text { information; only } \\
\text { minor revision } \\
\text { needed to reach } \\
\text { professional } \\
\text { standard. }\end{array}$ & $\begin{array}{l}\text { Almost all the } \\
\text { translation reads } \\
\text { like a piece } \\
\text { originally written } \\
\text { in English. There } \\
\text { maybe or spelling } \\
\text { errors, minor } \\
\text { lexical, } \\
\text { grammatical }\end{array}$ & Successful 9 & 10 \\
\hline Level 4 & $\begin{array}{l}\text { Almost complete } \\
\text { transfer; there } \\
\text { may be one or two } \\
\text { insignificant } \\
\text { inaccuracies; } \\
\text { requires certain } \\
\text { amount of } \\
\text { revision to reach } \\
\text { professional } \\
\text { standards }\end{array}$ & $\begin{array}{l}\text { Large sections } \\
\text { read like a piece } \\
\text { originally written } \\
\text { in English. There } \\
\text { are a number of } \\
\text { spelling lexical, } \\
\text { grammatical or } \\
\text { spelling errors. }\end{array}$ & $\begin{array}{l}\text { Almost } \\
\text { completely } \\
\text { successful }\end{array}$ & 7,8 \\
\hline Level 3 & $\begin{array}{l}\text { Transfer of the } \\
\text { general idea(s) but } \\
\text { with a number of } \\
\text { lapses in } \\
\text { accuracy; needs } \\
\text { considerable } \\
\text { revision to reach } \\
\text { professional } \\
\text { standard. }\end{array}$ & $\begin{array}{l}\text { Certain parts read } \\
\text { like a piece, but } \\
\text { others read like a } \\
\text { translation. There } \\
\text { are a considerable } \\
\text { number of lexical, } \\
\text { grammatical or } \\
\text { spelling errors. }\end{array}$ & Adequate & 5,6 \\
\hline Level2 & $\begin{array}{l}\text { Transfer } \\
\text { undermined by } \\
\text { serious } \\
\text { inaccuracies; } \\
\text { thorough revision } \\
\text { required to reach } \\
\text { professional } \\
\text { standard. }\end{array}$ & $\begin{array}{l}\text { Almost the entire } \\
\text { text reads like a } \\
\text { translation; there } \\
\text { are continual } \\
\text { lexical, } \\
\text { grammatical or } \\
\text { spelling errors. }\end{array}$ & Inadequate & 3,4 \\
\hline Level1 & $\begin{array}{l}\text { Totally inadequate } \\
\text { transfer of ST } \\
\text { content; the } \\
\text { translation is not } \\
\text { worth revising. }\end{array}$ & $\begin{array}{l}\text { The candidate } \\
\text { reveals a total lack } \\
\text { of ability to } \\
\text { express himself } \\
\text { adequately in } \\
\text { English }\end{array}$ & $\begin{array}{l}\text { Totally } \\
\text { inadequate }\end{array}$ & 1,2 \\
\hline
\end{tabular}

According to Waddington (2001, p.315), method D is "a mixture of error analysis based on Method B and holistic Method C in an appropriation of 70/30; that is to say that Method B accounts for $70 \%$ of the total result and Method C for the remaining $30 \%$ ".

Method C of Waddington's model was selected for the present research since it can be easily applied to translation tests.

The present research was worth effort as the result of the research, whether the hypothesis of the research was accepted or rejected, could be beneficial to translation agencies that are looking to hire translators, it help them a lot to decide who to hire who not to hire.

\section{Literature Review}

After spending a couple of weeks and reading many articles which had focused on both ideology and translation, the researcher found out that no one has ever focused on quality of translation of religious texts done by those who had different ideologies from ideologies of texts. There are many works which their main focuses are either on ideology or quality assessment. Many studies have been done on translation quality assessment and also translation of Islamic or religious texts and each of them have addressed a specific issue in order to help both translators and translation teachers to be able to provide better translations. One of the researches which has focused on both ideology and translation of Islamic texts is the work done by Ahmad Al-Harahsheh (2013) titled "Translation of Islamic Texts and Ideology". The 
researcher of the aforementioned research tried to find out if translations of those texts which had been written by a non-Muslim writer and then translated by both Muslim and non-Muslim translators were ideologically similar. The result of the study showed that Muslim translators were influenced by their religious beliefs when they were translating English to Arabic religious texts. The researcher concluded that:

..translators tend to add honorific expressions after the name of the prophet Muhammad and the other prophets. In addition, they add words after sacred places such as "Mecca, the sacred city" المكرمة مكة. Most importantly, they omit and replace words that denote negative connotations to mitigate their impacts; to manage the translated text according to their religious, cultural and social ideology (Al-Harahsheh, 2013, p. 114)

Another study is the research done by Abdunasir I. A. Sideeg (2015) titled "Traces of Ideology in Translating the Qurān into English: A Critical Discourse Analysis of Six Cases across Twenty Versions." As Sideeg (p.214) says, the main focus of the aforementioned research is on "nature and effect of traces of ideology on translating the Qurān in English and the way they shape the Qurānic message". Critical Discourse Analysis (CDA) is applied to this research in order to analyze the data. He justifies the application of CDA as "this approach provides a convenient mode of critical thinking to carry out the present thesis."

The texts are selected from the following list of twenty versions of the Quran into English, these versions are as follows:

1. Abdel Haleem, M. S: The Qurān

2. Ahmed, A. Al-Qurān: a contemporary translation

3. Ahmed, S. The Qurān as it Explains itself

4. Arberry, A.J.: The Koran interpreted

5. Asad, M.: The message of the Qurān

6. Bakhtiar, L.: The sublime Qurān

7. Bweley and Bweley: The noble Qurān: a new rendering of its meaning in English.

8. Busool, A.N.: The wise Qurān: a new

translation

9. Dawood, N. J.: the Koran

10. Haque-Khan: Kanz-ul-Eeman

11. Helminski, C. A.: The light of dawn: daily

readings from the holy Qurān
12. Hulusi-I: Decoding the Quran: a unique Sufi interpretation

13. Kahlifa, R.: Quran: the final testament, authorized English version of the original

14. Kidwai, A.: What is in the Qurān? Message of

the Qurān in simple English

15. Monotheist Group: The Qurān: a monotheist

translation

16. Qadri, T.: Irfan-ul-Quran

17. Sale, G. The Koran

18. Starkovsky, N.: The Koran handbook: an annotated translation

19. Tarazi's A: Allah's words in plain English

20. Yuksel, al-Shaiban and Schulte-Nafeh: A

Reformist Translation of the Qurān. (Sideeg, 2015, p.214)

For this study six texts were selected from twenty versions of the Qurān in English in ordered to be explored in terms of their salient features that reflect peculiar ideological readings, and at the end the researcher found out that:

1) All the six cases isolated in this article prove the strong and significant role of ideological and sectarian bias in shaping the course of translating the Qurān in English.

2) Drastic variations such as the use of the feminine pronoun 'she' for Allah (SWT) and the gnostic readings in Khalifa's 'Authorized Version' are essentially ideologically-motivated.

3) The 'gender-neutral' language [use of the pronoun $\mathrm{Hu}$ and the combination He/She in reference to Allah (SWT)] in translating the Qurān reflects complex traces of ideology as it is not motivated by the feminist movement alone. The case of Helminski, for instance, shows how the translator's cultural and linguistic backgrounds, Sufi doctrines, and feminist agenda all combine to produce an extremely radical and alien reading of the Qurān in English with regard to 'gender-neutral' issues.

4) The 'gender-neutral' approach in translating the Qurān contributes to the unjustified loss of core stylistic and discoursal features that are peculiar to the SL text. In Tarazi's version, for example, changing the system of pronouns in the Qurān would alter the essence of the Qurānic message.

5) In some instances, as in Rashad's Khalifa's versions discussed in case (3), it seems that ideology is the sole raison d'être for of translating the Qurān. Khalifa's Qurānist translation shows strong tendencies to reinterpret the Qurān in line with his gnostic claim of being the 'Messenger of the Covenant' and his rejection of the Prophet Muhammad's (PBUH) Hadith and Suna.

6) Sufi perspectives have their own legacy in interpreting particular personal pronouns to support certain Sufi and gnostic beliefs.

7) In translating the Qurān, ideological agendas may sometimes produce fictional scenarios which the SL text never accommodates. 
8) Neo-Mutazilte schemata contribute to some types of distortion in translating some personal pronouns in order to negate some miraculous events narrated in the Qurān.

9) The Qurānist traces of ideology are manifest in case (6). Within the ideological schemata of the Qurānists, the Prophet (PBUH) is only "a mailman of God," (Yuksel, 2003, p. 472) who has no role in explaining the message communicated in the Qurān. (Sideeg, 2015, p.225)

\section{Method}

\subsection{Procedures}

In order to have two homogenous groups, the researcher selected among those translators who had a B.A in the field of English to Persian translation which means all of them have passed all of the advanced translation courses and were familiar with translation of different types of texts specifically translation of religious texts. According to the syllabus of the field of English to Persian translation all of the B.A students have to pass four units related to translation of religious texts called "Assessing the Quality of Translation of Islamic Texts". The subjects were between 21 to 23 years old. Each subject was given five religious texts to translate from English into Farsi. Texts were all about Islam, and Prophet Mohammad written by a Muslim scholar, leader, theologian, philosopher, revivalist, and Islamic thinker, called Warith Deen Mohammed born in Michigan. Texts were selected from two of his books called "Al-Islam: The Articles of Faith (The Madh'hab Series)" and "MOHAMMED THE PROPHET (pbuh): The Perfect Man - The Complete Man".

The translations were scored based on method $\mathrm{C}$ of Waddington's model by two raters in order to increase the reliability of the results.

\subsection{Inter-Rater Reliability}

Inter-rater reliability was run for the present research to examine the reliability of the tests. Coefficient alpha was achieved by using SPSS22 software. Once the coefficient alpha is bigger than 0.8 it means that there is a significant agreement between the two raters who rated the subjects' translations of Islamic-religious texts, and it is ideal. For the present research the alpha was 0.994 which displays high reliability of tests.

\section{Results}

Given the nature of research question, quantitative data was collected and analyzed in order to answer the research question.

\subsection{Investigation of Research Question}

The research question was entitled "Does religious belief of a translator significantly affect the quality of his translations for religious texts?"

In this section, the results of the research will be explained. In order to do the analysis, inferential and descriptive statistics were run. Data is described in descriptive statistics, and central tendency and variability are used in order to describe the collected date. In inferential statistics, hypothesis testing is used in order to test the hypothesis of a research so this way we can generalize the data we gathered to the whole society.

Kolmogorov-Smirnov test was run for the present research to see if the distribution of the data was normal. The result of the aforementioned test is displayed in Table 2.

Table 2. One-Sample Kolmogorov-Smirnov Test

\begin{tabular}{ll}
\hline & Obtained scores \\
\hline Mean & 77.75 \\
SD & 10.577 \\
K-S & 0.601 \\
Sig. & 0.864 \\
\hline
\end{tabular}

According to the numbers in the Table 2 Sig. is 0.864 and it is bigger than 0.05 , so it means that the distribution of date was normal, and in order to examine the hypothesis of the research parametric test was run. The hypothesis for the aforementioned research question was that the quality of translation would not be affected by the religious belief of a translator. In order to compare the quality of translations of the two Muslim and non-Muslim groups, independent samples t-test was run. The results of the test are displayed in Table 3.

Table 3. Results of Independent Samples t-test

\begin{tabular}{llllll}
\hline Groups & $\mathrm{N}$ & Mean & $\mathrm{SD}$ & T-value & Sig. \\
\hline Muslim & 10 & 78.80 & 10.086 & & \\
$\begin{array}{l}\text { Non- } \\
\text { Muslim }\end{array}$ & 10 & 76.70 & 11.490 & 0.434 & 0.669 \\
\hline
\end{tabular}


According to the results of the Table 3, Sig. is 0.669 which is bigger than 0.05 and it means that there is no significant difference between the quality of translation of Muslin and non-Muslim groups, therefore the hypothesis of the research is accepted.

\section{Conclusion}

The researcher tried to fill the gap between all researches which have been done on Translation Quality Assessment and ideology separately. After doing the research titled "A Study of Translation Errors in Relation to Text Rhetorical Modes and Genre Types" in 2015, which was concluded that translators deliver higher quality translations for religious texts than for other texts namely, technical, literary and legal, and reading about the research which was done by Ahmad AlHarahsheh (2013), and also reading the result of Sideeg's work done in 2015, and getting more information about the effect of ideology on translation of the Qurān, which is a kind of religious texts and is the most important book among Muslims, the question came to the mind of the researcher to investigate and see what the result will be, if both ideology and translation quality assessment are combined knowing the facts that translators deliver high quality translations for religious texts and they are affected by their ideologies throughout the process of translation.

According to Lefevere's (2004, p.5) opinion, ideology is "a conceptual grid that consists of opinions and attitudes deemed acceptable in a certain society at a certain time, and through which readers and translators approach texts". Based on opinions of many translation scholars, there is no doubt that ideology of a translator can color his translations, as Aichele (2002) believes "no translation is ever complete. The selection of possible meanings to be excluded or included is always ideological". It is really important especially for readers to read translations which convey the true meaning and ideology of the source text. A translation which is ideologically far from the original text is not a translation anymore, it is like a new text and the translator would be like a writer. Sometimes ideology of an original text is really important to both writer of the text and reader of the translated version of the source text, and religious texts are one of those texts which their ideologies are their most important aspects. So here the question is, if the ideology of a translator can be applied to a text, does it have the power to affect the quality of a translation? Effect of ideology is so important that so far many studies have been done on the effect of ideology on translation of different texts including political, Islamic, literary texts and so on. It is really important to do researches that focus on effect of ideology on translation of religious texts in a country like Iran which the majority of people are Muslims and religious and specifically Islamic texts are important to them.

TQA is one of the most important subjects focused by many scholars lately, as it focuses on the quality of translation and performance of translators at the end which is very helpful to those who are looking for higher quality translations and those who try to train better translators. House (2001) posed the simplest question about the quality of translation that what a good translation is! Many translation scholars tried to answer this question and Halliday (2001) believes it is hard to say which translation is good. There are many ways to assess the quality of translation, and Waddington's model is one of those ways which was selected for the present research.

As so far no research has been done on quality of translations of religious texts, the present research was conducted to investigate if the religious belief of a translator forces him to provide a higher quality translation, or in other words, to see if religious belief of a translator can affect the quality of his translations. According to the analysis of the data presented before, the hypothesis of the researcher was accepted; it means that there is no relationship between the religious beliefs of a translator and the quality of translation he delivers. In order to achieve this result, a KolmogorovSmirnov test was run to see if the data had a normal distribution, after that a parametric test was run to compare the quality of translation of the two groups of translators, a t-test was also run and as the results showed the "Sig." was bigger than 0.05 which means that there was no significant difference between the quality of translations of Muslim and non-Muslim group. Based on the result of the present research and by taking into account the results of the aforementioned studies which were done on ideology of translators, it can be said that although ideology can affect a translator by forcing him to select specific words, for example for showing more respect to those things that are important to him, or using 'gender-neutral' approach or feminine pronoun for Allah or so on in translation of the Quran, which is the most important book to Muslims, and is much more important than any Islamic-religious texts, ideology of a translator cannot affect the quality of his translations, in other words, ideology cannot weaken performance of a translator who translates texts which are ideologically different from his own ideology. It's good to bear in mind that all of the subjects of the present research believed in God, they just believed in different religions, in other words, they were not against each other.

Doing a study which assesses the quality of translations which are done by Muslim translators but ideologies of the original texts are totally against the ideology of Islam, is suggested for further research. By doing such research it will be concluded that how high or low the quality of a translation is, if a translator has to translate a text which its ideology is totally in contrast with his own ideology, like all those texts which are written by atheist writers. The subjects of the present research were all believers in God and all of them had divine religions, but for further research it is good to investigate how good the quality of translations of texts written by non-believers about atheism, for instance, will be if they are done by Muslim translators.

One of the characteristics of a good translator is to provide a good translation, which means producing a high quality translation, and those who produce high quality translations have higher chance of finding jobs as translators. The result of the present research can be useful for translation agencies and those who are willing to hire translators especially for translation of religious texts, since based on the result of the present research, disregard of the religious beliefs of a 
translator he can deliver a high quality translation if he is a well educated translator who knows the characteristics and difficulties of religious texts and knows how he should deal with such texts.

The main limitation of the present research was finding non-Muslim translators who had a B.A in the field of English to Persian translation. As Iran is an Islamic country and the majority of people who live in Iran are Muslims, it was a really hard and time consuming process to find the translators who were not Muslims.

\section{References}

Aichele, G. (2002). Translation as de-canonization: Matthew's Gospel according to Pasolini. Retrieved from http://home.comcast.net/ gcaichele/writings/pasolinimatthew.pdf

Al-Harahsheh, A.(2013). Translation of Islamic Texts and Ideology. Retrieved from

http://faculty.yu.edu.jo/harahsheh/Lists/Published\%20Research/Attachments/6/translation\%20of\%20islamic\%20texts\% 20and\%20ideology.pdf

Ehteshami, Z. (2015). the impact of ideology on translation: a case in Iran. Retrieved from http://www.ijllalw.org/finalversion8118.pdf

Dickins, J., Hervey, S., \&Higgins, I. (2002). Thinking Arabic Translation: A Course in Translation Method:Arabic to English. Retrieved from www.libgen.com

Dweik, B. \& Abu Helwah, W. (2014). Translating Historical and Religious Texts from Arabic into English: Problems and Solutions. Retrieved from http://www.hebron.edu/docs/journal/B-Humanities/v9-1/Vol9No1.285-303.pdf

Elewa, A. (2014). Features of Translating Religious Texts. Retrieved from https://www.sil.org/system/files/reapdata/16/93/14/.../siljot2014_1_04.pdf

Farsian, M. \& Esmaieli, N. (2004). Investigating the importance of translation of religious Islamic text, A case study in French language. Retrieved from https://www.civilica.com/PdfExport-CONFIR01_103

Gambier, Y., \& Doorslaer, L. (2010). Handbook of translation studies. John Benjamins Publishing Company. (Vol. 1). Retrieved from http://libgen.info/view.php?id=919579

Halliday, M.A.K. (2001). Towards a theory of Good translation. In Steiner, E \& Yallop, C. (Ed.), Exploring Translation and Multilingual Text Production: Beyond Content, 13-18. Berlin: Mouton de Gruyter.

Harrison, V. S. (2007). Metaphor, Religious Language and Religious Experience. University of Glasgow, July 2007 , Volume 46, Issue 2, pp127-145

Hatim B. \& Mason, I. (1997). The translator as communicator. London, Routledge

House, J. (2015). Translation Quality Assessment Past and Present. First published 2015 by Routledge 2 Park Square, Milton Park, Abingdon, Oxon OX14 4RN

House, J. (2001). Translation quality assessment: Linguistic description versus social evaluation. Meta, 46(2), $243-257$.

Jahanshahi, M. \& Kafipour, R. (2015). Error Analysis of English Translation of Islamic Texts by Iranian Translators. Retrieved from http://www.jallr.com/index.php/JALLR/article/view/57

Khanmohammad, H \&Osanloo, M. (2009). Moving toward objective scoring: A rubric for translation assessment. Retrieved from http://sid.ir/en/VEWSSID/Jpdf/1032120090108.pdf

Lefevere, A. (2004). Translation, rewriting and the manipulation of literary fame. Routledge.

Lopez, A. \& Ramos Caro, M. (2014). The Impact of Translator's Ideology on the Translation Process: A Reaction Time Experiment. Retrieved form

https://rua.ua.es/dspace/bitstream/10045/43728/1/MonTI_2014_Special_Issue_09.pdf

Naeem, H. Andleeb, A., Nadvi, N., Umar, M., Shabir, S. \& Shabir, G. (2014). LANGUAGE OF RELIGION. Retrieved from http://meritresearchjournals.org/assh/Content/2014/June/Naeem\%20et\%20al.pdf

Rabani, H. (2007). Difficulties of translating religious texts. Seasonal journal of Hadith and Scientific Research. 4th and 3rd No, 12th year.

Schaffner, C. (2003) Third ways and new centers: Ideological unity or difference? In M. Calzada-Perez (ed.), Apropos of ideology (PP. 23-42). Manchester: St. Jerome.

Sideeg, A. (2015). Traces of Ideology in Translating the Qurān into English: A Critical Discourse Analysis of Six Cases across Twenty Versions. Retrieved from www.journals.aiac.org.au/index.php/IJALEL/article/download/1585/1525

Tymoczko, M. (2003). Ideology the position of the translator: In what Sense is a translator 'in between' ? In M. Calzada-Perez (ed.), Apropos of ideology (pp.181-202). Manchester: St. Jerome

Waddington, C (2001). Should translations be assessed holistically or through error analysis? Retrieved form http://download2.hermes.asb.dk/archive/download/h26_03.pdf

Williams, M. (2009). Translation quality. Retrieved form

http://revinut.udea.edu.co/index.php/mutatismutandis/article/viewFile/1825/1609

Xiao-jiang, Y. (2007). On the Role of Ideology in Translation Practice. US-Foreign Language, 4(43), 63-65.

Yousefi, S. (2015). A Study of Translation Errors in Relation to Text Rhetorical Modes and Genre Types. Retrieved form www.jallr.com/index.php/JALLR/article/download/52/pdf_50 